\title{
Post Monsoon Analysis of Physico-Chemical Parameter of Surface and Ground Water Samples In (Arang Block) Raipur Districts, Chhattisgarh, India
}

\author{
Mrs. Pramisha Sharma ${ }^{1}$, Dr. Amit Dubey ${ }^{2}$, Dr. S.K. Chatterjee ${ }^{3}$ \\ ${ }^{I}$ Asst. Prof. and Research Scholar, Chemistry, M.M. College of Technology, Raipur (C.G.) INDIA. \\ ${ }^{2}$ Senior Scientist, Chhattisgarh Council of Science and Tecnology, Raipur (C.G.) INDIA. \\ ${ }^{3}$ Principal, Govt. Arts, Commerce and Science College, Tilda, Distt. Raipur (C.G.) INDIA.
}

\begin{abstract}
The study was carried out to assess surface and ground water quality of the (Arang block) in Raipur districts. The study area is situated between latitude 21.195 and longitude 81.967. Detailed survey by random samples was collected 8 different sites in Arang block and was analyzed for different Physico-Chemical parameters $\mathrm{pH}$, electrical conductivity, alkalinity, hardness and chloride. The results were compared with BIS .By observing the result it can be concluded that the parameters which were taken for study the water quality are below the pollution level for ground as well as surface water which satisfy the requirement for the use of various purposes like domestic, agricultural, industrial etc.
\end{abstract}

Key words: Post monsoon, Ground water, Surface water, Physico-Chemical parameter, Raipur Districts.

\section{Introduction}

Natural resources are the important wealth of our country; water is one of them 1 . Water is a wonder of the nature, "No life without water" is a common saying depending upon the fact that water is the one of the naturally occurring essential requirement of all life supporting activities 2.Since it is a dynamic system, containing living as well as nonliving organic, inorganic , soluble as well as insoluble substances. So its quality is likely to change day by day and from source to source. Any change in natural quality may disturb the equilibrium system and would become unfit for designated uses. The availability water through surface and ground water resources has become critical day by day. Only $1 \%$ part is available on land for drinking, agriculture, domestic, power generation, industrial consummation, transportation and west disposal 3. In India, most of the population is dependent surface water (dame water) as the only source of drinking water supply. The ground water believed to be comparatively much clean and free from pollution then surface water. But prolonged discharge of industrial effluents, domestic sewage and solid waste dump causes the groundwater to become populated and created health problems 4 . The rapid growth of urban areas has further affected groundwater quality due to over exploitation of resources and improper waste disposal practices. Hence, there is always a need for and concern over the protection and management of surface water and ground water quality 5 .

The consequence of urbanization and industrialization leads to spoil the water. For agricultural purposes ground water is explored in rural areas especially in those areas where other sources of water like dam and river or the canal is available. During last decade, this is observed that the surface water get polluted drastically because of increased human activities 67 . The present study was undertaken to investigate the impact of the surface water quality of some river and other bodies of surface water samples. Thus, in this research work an attempt has been made to assess the physical and chemical parameters of surface and ground water like, Temperature (T), pH, electrical conductivity (EC), total dissolved solids (TDS), total alkalinity (TA), total hardness $(\mathrm{TH})$ and chloride. The analyzed data were compared with standard values recommended by BIS and WHO 8.

\section{Materials And Method}

SAMPLING \& PRESERVATION: - The water samples were drawn during post monsoon (Nov-Jan). The ground and surface water were collected from different wards of (Arang Block) in Raipur district C.G. water samples from different location were collected in the sample bottles of $250 \mathrm{ml}$ from well. Bore well, pond and tape water. Sample collected were analyzed in 2 days go no special preservation required. However sample in the bottles were kept in the refrigerator. Standard testing methods are used to analyze metals and different parameter?.

The $\mathrm{pH}$ of the ground water was estimated by $\mathrm{pH}$ meter. The alkalinity of water is generally due to present of carbonate and hydroxide ion. Alkalinity provides an idea of the nature of salts present in the water.

The total alkalinity of ground water was calculated by standard titration method. The total solid (TS) present in $100 \mathrm{ml}$ of sample water was at $103^{\circ}$ to $105^{\circ} \mathrm{c}$ to dryness in drying oven. Cooling it in desiccators and 
then weight. The TS in $\mathrm{mg} / \mathrm{l}$. $=(\mathrm{A}-\mathrm{B}) \times 100 /$ sample volume in liter. Where $\mathrm{A}=$ weight of $($ dried residue + dish $) \&$ $\mathrm{B}=$ weight of dish. The total suspended solid (TSS) was calculated by the following formula: Total suspended solid $(\mathrm{mg}) /$ litre $=(\mathrm{A}-\mathrm{B}) \times 100 /$ sample vol. in litre, where, $\mathrm{A}=$ weight of filter + dried residue. $\mathrm{B}=$ weight of filter paper. The total dissolved solids (TDS) term is used to describe the inorganic salts and small amount of organic matter present in solution. It was calculated by adding calcium and magnisium hardness derived by EDTA titration method. The chloride was estimated by silver nitrate titration method. Temperature of the samples measure by thermometer.

\section{Results \& Discussion}

Post monsoon analysis of physico-chemical characteristics of surface and ground water of the study area (Arang Block) of Raipur District

Table: 1 Post monsoon analysis of physico-chemical characteristics of Tap water samples in (Arang Block) of

\begin{tabular}{|c|c|c|c|c|c|c|c|c|c|c|c|}
\hline $\begin{array}{l}\text { paramet } \\
\text { er }\end{array}$ & $\begin{array}{c}\text { BIS- } \\
\text { standards }\end{array}$ & $\begin{array}{l}\text { Lakh } \\
\text { oli } \\
(1)\end{array}$ & $\begin{array}{l}\text { Kris } \\
\text { ak n } \\
\text { agar } \\
(2)\end{array}$ & $\begin{array}{l}\text { Chand } \\
\text { khuri } \\
\text { (3) }\end{array}$ & $\begin{array}{c}\text { cherikh } \\
\text { eri (4) }\end{array}$ & $\begin{array}{l}\text { Mand } \\
\text { ir } \\
\text { hasud } \\
(5)\end{array}$ & $\begin{array}{c}\text { Nawago } \\
\text { an (6) }\end{array}$ & $\begin{array}{l}\text { Umari } \\
\text { a (7) }\end{array}$ & $\begin{array}{l}\text { Lakholi } \\
\text { (8) }\end{array}$ & $\begin{array}{c}\text { Budeni } \\
\text { (9) }\end{array}$ & $\begin{array}{c}\text { Arang } \\
(10)\end{array}$ \\
\hline & $(\mathrm{mg} \mid \mathrm{l})$ & Tw1 & TW2 & TW3 & TW4 & TW5 & TW6 & TW7 & TW8 & TW9 & TW10 \\
\hline $\mathrm{pH}$ & $6.5-9.2$ & 7.9 & 7.5 & 8 & 8.8 & 7.3 & 8.1 & 7.3 & 7.9 & 7.4 & 7.9 \\
\hline $\begin{array}{l}\text { ALKA } \\
\text { LINIT } \\
\text { Y }\end{array}$ & $\begin{array}{l}\text { Desirable } \\
200 \mathrm{mg} / \mathrm{l} \text {. } \\
\text { permissible } \\
600 \mathrm{mg} / 1 \\
\end{array}$ & 110 & 260 & 300 & 280 & 270 & 290 & 240 & 300 & 110 & 300 \\
\hline $\begin{array}{l}\text { HARD } \\
\text { NESS }\end{array}$ & $\begin{array}{l}\text { Desirable } \\
300 \mathrm{mg} / \mathrm{l} \text {. } \\
\text { permissible } \\
600 \mathrm{mg} / 1\end{array}$ & 280 & 240 & 150 & 200 & 100 & 140 & 130 & 110 & 190 & 100 \\
\hline $\begin{array}{l}\text { CHLO } \\
\text { RIDE }\end{array}$ & $\begin{array}{l}\text { Desirable } \\
250 \mathrm{mg} / \mathrm{l} . \\
\text { permissible } \\
10000 \mathrm{mg} /\end{array}$ & 80 & 50 & 40 & 50 & 40 & 70 & 70 & 70 & 90 & 20 \\
\hline $\begin{array}{l}\text { TEMP } \\
\text { ERAT } \\
\text { URE } \\
\end{array}$ & & 22.3 & 23.1 & 23.8 & 22.2 & 23 & 22.6 & 23.2 & 23 & 22.7 & 22.5 \\
\hline
\end{tabular}

Table No.2 Post monsoon analysis of physico-chemical characteristics of Bore-well water samples in (Arang Block) of District Raipur

\begin{tabular}{|c|c|c|c|c|c|c|c|c|c|c|c|}
\hline $\begin{array}{l}\text { parame } \\
\text { ter }\end{array}$ & $\begin{array}{c}\text { BIS- } \\
\text { standards }\end{array}$ & $\begin{array}{l}\text { Lakh } \\
\text { oli } \\
(1)\end{array}$ & $\begin{array}{c}\text { Kris } \\
\text { ak n } \\
\text { agar } \\
(2)\end{array}$ & $\begin{array}{c}\text { Chan } \\
\text { dkhur } \\
\text { i } \\
(3)\end{array}$ & $\begin{array}{c}\text { cherik } \\
\text { heri } \\
(4)\end{array}$ & $\begin{array}{c}\text { Man } \\
\text { dir } \\
\text { hasu } \\
\text { d (5) }\end{array}$ & $\begin{array}{l}\text { Nawag } \\
\text { oan (6) }\end{array}$ & $\begin{array}{c}\text { Umari } \\
\text { a (7) }\end{array}$ & $\begin{array}{c}\text { Lakholi } \\
\text { (8) }\end{array}$ & $\begin{array}{c}\text { Budeni } \\
\text { (9) }\end{array}$ & $\begin{array}{c}\text { Arang } \\
(10)\end{array}$ \\
\hline & $(\mathrm{mg} \mid \mathrm{l})$ & BW1 & $\begin{array}{c}\text { BW } \\
2\end{array}$ & BW3 & BW4 & BW5 & BW6 & BW7 & BW8 & BW9 & BW10 \\
\hline $\mathrm{pH}$ & $6.5-9.2$ & 8.2 & 7.5 & 7.7 & 7.3 & 7.6 & 7.4 & 7.3 & 7.1 & 7.2 & 7.1 \\
\hline $\begin{array}{l}\text { ALKA } \\
\text { LINIT } \\
\text { Y }\end{array}$ & $\begin{array}{l}\text { Desirable } \\
200 \mathrm{mg} / \mathrm{l} \text {. } \\
\text { permissible } \\
600 \mathrm{mg} / 1\end{array}$ & 250 & 140 & 140 & 80 & 110 & 160 & 140 & 130 & 210 & 150 \\
\hline $\begin{array}{l}\text { HARD } \\
\text { NESS }\end{array}$ & $\begin{array}{l}\text { Desirable } \\
300 \mathrm{mg} / \mathrm{l} \text {. } \\
\text { permissible } \\
600 \mathrm{mg} / 1\end{array}$ & 80 & 220 & 100 & 130 & 140 & 280 & 250 & 200 & 100 & 120 \\
\hline TDS & $\begin{array}{l}\text { Desirable } \\
500 \mathrm{mg} / \mathrm{l} \text {. } \\
\text { permissable } \\
2000 \mathrm{mg} /\end{array}$ & 492 & 528 & 336 & 382 & 348 & 576 & 612 & 528 & 444 & 372 \\
\hline $\begin{array}{l}\text { CHLO } \\
\text { RIDE }\end{array}$ & $\begin{array}{l}\text { Desirable } \\
250 \mathrm{mg} / 1 . \\
\text { permissible } \\
10000 \mathrm{mg} /\end{array}$ & 80 & 80 & 40 & 110 & 40 & 30 & 120 & 110 & 60 & 40 \\
\hline $\begin{array}{l}\text { TEMP } \\
\text { ERAT } \\
\text { URE } \\
\end{array}$ & & 22.3 & 23 & 23 & 22.1 & 23.4 & 23.1 & 22.6 & 22.1 & 22.3 & 23.1 \\
\hline
\end{tabular}


Table: 3 Post monsoon analysis of physico-chemical characteristics of well water samples in (Arang Block) of District Raipur

\begin{tabular}{|c|c|c|c|c|c|c|c|c|c|c|c|}
\hline $\begin{array}{l}\text { param } \\
\text { eter }\end{array}$ & $\begin{array}{c}\text { BIS- } \\
\text { standards }\end{array}$ & $\begin{array}{l}\text { Lak } \\
\text { holi } \\
\text { (1) }\end{array}$ & $\begin{array}{l}\text { Kris } \\
\text { ak n } \\
\text { agar } \\
(2)\end{array}$ & $\begin{array}{l}\text { Chan } \\
\text { dkhur } \\
\text { i } \\
\text { (3) }\end{array}$ & $\begin{array}{l}\text { cherik } \\
\text { heri } \\
(4)\end{array}$ & $\begin{array}{c}\text { Man } \\
\text { dir } \\
\text { hasu } \\
\text { d (5) }\end{array}$ & $\begin{array}{l}\text { Nawag } \\
\text { oan (6) }\end{array}$ & $\begin{array}{l}\text { Umari } \\
\text { a (7) }\end{array}$ & $\begin{array}{l}\text { Lakhol } \\
\text { i (8) }\end{array}$ & $\begin{array}{c}\text { Budeni } \\
\text { (9) }\end{array}$ & $\begin{array}{c}\text { Arang } \\
(10)\end{array}$ \\
\hline & $(\mathrm{mg} \mid \mathrm{l})$ & $\begin{array}{r}\text { WW } \\
1 \\
\end{array}$ & $\begin{array}{r}\text { W } \\
\text { W2 } \\
\end{array}$ & $\begin{array}{r}\text { WW } \\
3 \\
\end{array}$ & WW4 & $\begin{array}{r}\text { WW } \\
5 \\
\end{array}$ & WW6 & WW7 & WW8 & WW9 & WW10 \\
\hline $\mathrm{pH}$ & $6.5-9.2$ & 7.5 & 7.8 & 7.9 & 7.8 & 7.2 & 7.3 & 7.5 & 7.8 & 7.9 & 8 \\
\hline $\begin{array}{l}\text { ALKA } \\
\text { LINIT } \\
\text { Y }\end{array}$ & $\begin{array}{l}\text { Desirable } \\
200 \mathrm{mg} / 1 . \\
\text { permissible } \\
600 \mathrm{mg} / 1 \\
\end{array}$ & 60 & 100 & 80 & 90 & 200 & 160 & 100 & 100 & 110 & 140 \\
\hline $\begin{array}{l}\text { HARD } \\
\text { NESS }\end{array}$ & $\begin{array}{l}\text { Desirable } \\
300 \mathrm{mg} / \mathrm{l} \text {. } \\
\text { permissible } \\
600 \mathrm{mg} / 1 \\
\end{array}$ & 120 & 100 & 80 & 90 & 110 & 80 & 110 & 80 & 100 & 90 \\
\hline TDS & $\begin{array}{l}\text { Desirable } \\
500 \mathrm{mg} / \mathrm{l} \text {. } \\
\text { permissible } \\
2000 \mathrm{mg} /\end{array}$ & 276 & 336 & 264 & 312 & 420 & 372 & 312 & 280 & 444 & 504 \\
\hline $\begin{array}{l}\text { CHLO } \\
\text { RIDE }\end{array}$ & $\begin{array}{l}\text { Desirable } \\
250 \mathrm{mg} / 1 . \\
\text { permissible } \\
10000 \mathrm{mg} /\end{array}$ & 50 & 80 & 60 & 80 & 40 & 70 & 50 & 70 & 50 & 40 \\
\hline $\begin{array}{l}\text { TEMP } \\
\text { ERAT } \\
\text { URE } \\
\end{array}$ & & 23 & 22.1 & 22.1 & 23 & 22.1 & 23 & 23.1 & 23.1 & 22 & 23.1 \\
\hline
\end{tabular}

Table: 4 Post monsoon analysis of physico-chemical characteristics of pond water samples in (Arang Block) of District Raipur

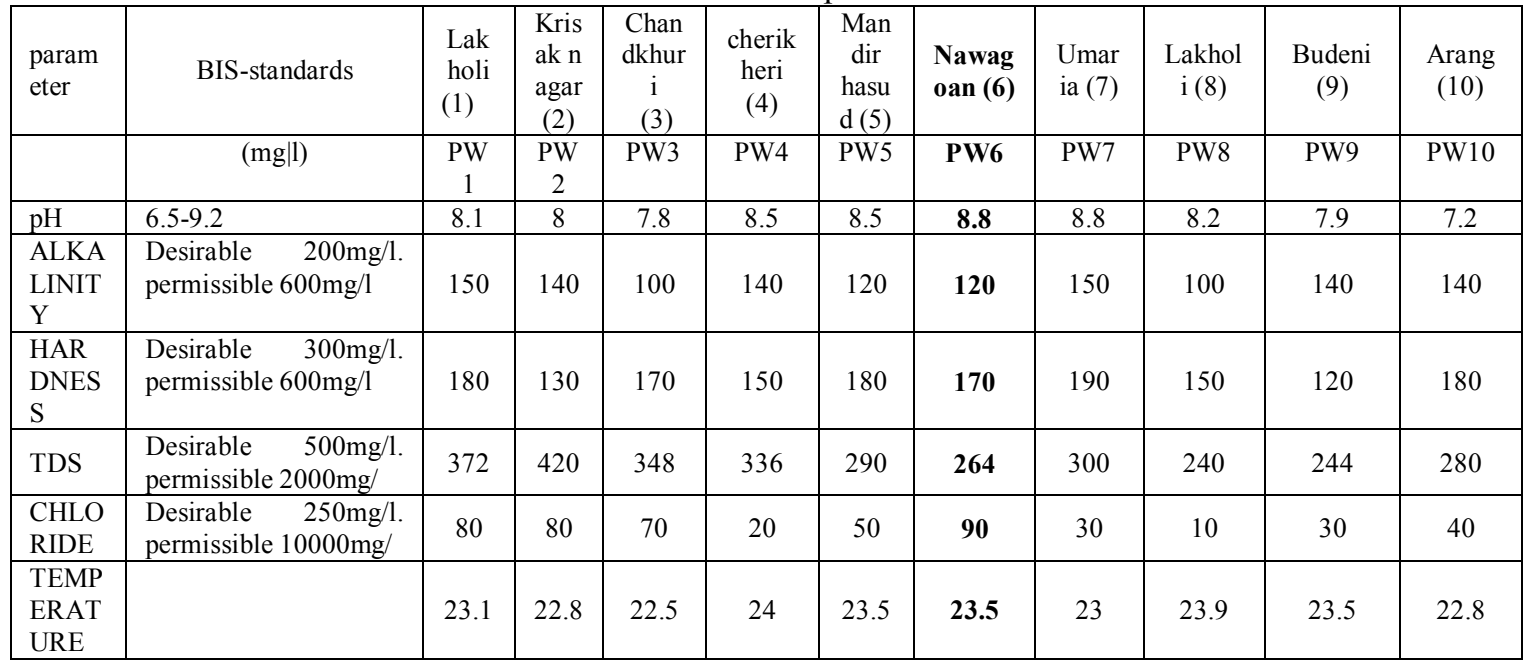

\section{Temperature}

The temperature of tape water ranged from a minimum of $22{ }^{\circ} \mathrm{C} \pm .5{ }^{0} \mathrm{C}$ to a maximum of $23.5^{0} \mathrm{C} \pm .5^{0} \mathrm{C}$ in ward no 4, 1, 10, 9 and 5,2,7,6,and 3 respectively (Table-1). Similarly the variation in temperature of a bore well water ranged from a minimum $22{ }^{0} \mathrm{C} \pm .5{ }^{0} \mathrm{C}$ to a maximum $23+-.5{ }^{0} \mathrm{C}$ in ward no. 8,4,9,1,7 and 2,3,10,6,5 respectively (Table-2). The temperature of well water ranged minimum of $22{ }^{0} \mathrm{C} \pm .2{ }^{0} \mathrm{C}$ and maximum $23{ }^{0} \mathrm{C} \pm$ $.1{ }^{\circ} \mathrm{C}$ in ward no. 9,5,2,3,7and 1,6,4,7,8 respectively (Table-3). The temperature of pond water ranged minimum of $22.5{ }^{0} \mathrm{C} \pm .4{ }^{0} \mathrm{C}$ and maximum $23.5{ }^{\circ} \mathrm{C} \pm .5^{0} \mathrm{C}$ in ward no.3,10,2, and 4,8,6,5,7 and 1 respectively (Table-4).

During the present investigation, there was no great difference between the temperature of the tape water, bore well, well and pond water.

pH

The $\mathrm{pH}$ of tap water from a minimum of $7.5 \pm .5$ and maximum of $8.3 \pm .5$ of ward no. 7,5,9,2,1,8,9 ands,6,3 respectively (Table-1). Similarly the variation of $\mathrm{pH}$ of bore- well water ranged from a minimum $7 \pm .5$ and maximum $8 \pm .3$ of ward no. 8,10,4,7,6,5,2and 3,1 respectively (Table-2). Similarly the variation of $\mathrm{pH}$ of well water ranged from a minimum $7.2 \pm .5$ and maximum $7.5 \pm .5$ in ward no. 5,6,7,1,4,2,8 and 3,9 (Table-3). The $\mathrm{pH}$ of pond water ranged from a minimum $7.3+-.5$ and maximum $8.2 \pm .5$ of ward no. 9,3 and 
6,7,4,5,8 1 respectively(Table-4). The results show that water quality of Arang block shows no remarkable variation from the BIS recommended value of $\mathrm{pH}$.

\begin{abstract}
Alkalinity
(Table-1) represent the variation in total alkalinity of tape water ranged from a minimum of $110 \mathrm{mg} / \mathrm{l}$. and maximum of $300 \mathrm{mg} / \mathrm{l}$. in ward no.1,9, and 3,8,10. Similarly the variation in total alkalinity of bore well water ranged from minimum $80 \mathrm{mg} / \mathrm{l}$. and maximum $250 \mathrm{mg} / \mathrm{l}$. in a ward no. 4 and 1 respectively (Table-2). The alkalinity of well water ranged from minimum of $60 \mathrm{mg} / 1$. and maximum $200 \mathrm{mg} / \mathrm{l}$. in a ward no. 1 and 5 respectively (Table-3). Similarly the alkalinity ranged from pond water was minimum $100 \mathrm{mg} / \mathrm{l}$. and maximum $150 \mathrm{mg} / \mathrm{l}$. in a ward no. 3,8 and 1,7 respectively (Table-4). The alkalinity of some places was above and some places were below the BIS desirable level $200 \mathrm{mg} / \mathrm{l}$. in all the samples of ground and surface water but was less than the maximum permissible limit.
\end{abstract}

\title{
Hardness
}

The Hardness of tape water ranged from a minimum $100 \mathrm{mg} / \mathrm{l}$. and maximum of $280 \mathrm{mg} / \mathrm{l}$. in ward no. 5,10 , and 1 respectively (Table-1). Similarly the variation in hardness of bore well water ranged from a minimum $80 \mathrm{mg} / 1$. and maximum of $280 \mathrm{mg} / \mathrm{l}$. in ward no. 1 and 6 respectively (Table-2). The hardness of well water ranged from a minimum $80 \mathrm{mg} / \mathrm{l}$. and maximum of $120 \mathrm{mg} / 1$. in ward no. 3 and 1 respectively (Table-3).

Similarly the hardness ranged of pond water from a minimum $120 \mathrm{mg} / \mathrm{l}$. and maximum 180 in ward no. 9 and 10 respectively (Table-4). In present investigation the total hardness to be equal the BIS desirable level of $300 \mathrm{mg} / \mathrm{l}$.

\section{Total Dissolved Solid (Tds)}

The total dissolved solid of tape water ranged from a minimum $264 \mathrm{mg} / \mathrm{l}$. and maximum $660 \mathrm{mg} / \mathrm{l}$. in ward no. 1 and 2 respectively (Table-1). Similarly the variation of total dissolved solid of bore well water ranged from a minimum $336 \mathrm{mg} / \mathrm{l}$. and maximum $612 \mathrm{mg} / \mathrm{l}$. respectively (Table-2). The total dissolved solid of well water ranged from a minimum $262 \mathrm{mg} / \mathrm{l}$. and maximum 504mg/l. in ward no. 3 and 10 respectively (Table3). Similarly the total dissolved solid of pond water ranged from a minimum $240 \mathrm{mg} / \mathrm{l}$. and maximum $420 \mathrm{mg} / \mathrm{l}$. in ward no. 8 and 2 respectively (Table-4). The water samples of all the wards contains higher amounts of TDS than the desirable limits. The maximum TDS was detected in Krisak nagar $660 \mathrm{mg} / \mathrm{l}$. in Arang block.

\section{CHLORIDE}

(Table-1) represent the variation in total chloride of tape water ranged from a minimum of $20 \mathrm{mg} / \mathrm{l}$. and maximum of $90 \mathrm{mg} / \mathrm{l}$. in ward no. 10 and 9 . Similarly the chloride of bore well water ranged from minimum 30 $\mathrm{mg} / \mathrm{l}$. and maximum $120 \mathrm{mg} / \mathrm{l}$. in a ward no. 6 and 7 respectively (Table-2). The chloride of well water ranged from minimum of $40 \mathrm{mg} / 1$. and maximum $80 \mathrm{mg} / 1$. in a ward no. 5,10, and 2,3 (Table-3). Similarly the variation of chloride ranged from pond water ranged from minimum $20 \mathrm{mg} / \mathrm{l}$. and maximum 90 in a ward no. 4 and 6 respectively (Table-4). In present investigation the chloride content of Arang block less then the BIS desirable level $250 \mathrm{mg} / \mathrm{l}$.

\section{Conclusion}

The study assessed the evolution of water quality in ground water and surface water of Arang Block in Raipur District. A comparative study of both type of ground water and surface water was carried out by taking certain important parameters like temperature, $\mathrm{PH}$, total dissolved solid, alkalinity, hardness and chloride .

The water samples of all the Arang block contain higher amount of TDS than the desirable limits. No sample crossed the maximum permissible limit for TDS Alkalinity, hardness chloride and PH.

In this present investigation it was found that the maximum parameters were not at the level of pollution. So both type of ground water satisfy the requirement for the use in various purposes.

\section{Acknowledgement}

The Authors thankfully acknowledge to Dr. A.S. Zadgaonkar Vice chancellor Dr C.V. Raman University (Kota) Bilaspur. Prof.M.M. Hambarde Diroctor General, Chhattisgarh Council of Science \& Technology Raipur, Dr. Shamita Chakraborty, Director M M College of technology Raipur, Dr. B.D. Diwan Asstt. Prof. Govt. College Champa, Prof.N.V. Deshpandy M M College of Technology, Raipur, Dr. Beena Sharma, Junior Scientist, Chhattisgarh Council of Science \& Technology, Dr. S.S. Joshi , Ex-Hod, NIT, Raipur (C.G.), Dr A.N. Jha, Dean Acad.,MM College for their valuable and motivational support to carry out this research. 


\section{Journals Papers:}

\section{Reference}

[1]. Basavaraja Simpi, S.M. Hiremath, KNS Murthy; Analysis of Water Quality Using Physico-Chemical Parameter Hosahalli Tank in Shimoga District, Karnataka,India Global journal of Science Frontier Research,11(3). (2011).

[2]. S. Julie Ranee and S. Vasantha; Physico-Chemical analysis of bore well water samples of anaiyur area in Madurai district, Tamilnadu, INDIA J. Curr. Sci. 15 (2) : 403-408 (2010).

[3]. 3. Raja R. E, Lydia Sharmila, Princy Merlin, Chritopher G, Physico-Chemical analysis of Some Groundwater Samples of Kotputli Town Jaipur, Rajasthan, India J Environ Prot., 22(2), 137, (2002).

[4]. Patil P. R, Badgujar S. R. and Wark A. M. Evolution of Ground Water Quality In Ganesh Colony Area Of Jalgaon City, Orintal J Chem., 17 (2), 283, (2001).

[5]. Lokeshwari H and Chandrappa G. T., Impact of heavy metal contamination of Bellandur Lake on soil and cultivated vegetation , Curr Sci., 91 (5), 584, (2006).

[6]. Massod Alam ,Sumbul Rais and Mohd Aslam S; Hydro-chemical Survey of Groundwater of Delhi, India, E-Jour. Of Chem. 6(2), 429-436,(2009).

\section{Books:}

[7]. Petrus R. and Warchol J. K., Heavy metal removal by clinoptilolite. An equilibrium study in multi-component systems, Water Res., 39,819-830 (2005).

[8]. Elizabeth K. M. and Premnath Naik L, Effect of polluted water On human health Poll. res., 24(2), 337-340, (2005).

[9]. APHA, "Standard method for examination of water and waste water." American Public Health Association, Washington, D.C. 1989. 